\title{
Gyroidal nanoporous carbons - Adsorption and separation properties explored using computer simulations $]^{*}$
}

\author{
S. Furmaniak ${ }^{1}$, P.A. Gauden ${ }^{1}$, A.P. Terzyk ${ }^{1}$, P. Kowalczyk $k^{12}$ \\ ${ }^{1}$ Faculty of Chemistry, Physicochemistry of Carbon Materials Research Group, \\ Nicolaus Copernicus University in Toruń, Gagarin St. 7, 87-100 Toruń, Poland \\ 2 School of Engineering and Information Technology, Murdoch University, \\ Murdoch, Western Australia 6150, Australia
}

Received November 13, 2015, in final form December 17, 2015

\begin{abstract}
Adsorption and separation properties of gyroidal nanoporous carbons (GNCs) - a new class of exotic nanocarbon materials are studied for the first time using hyper parallel tempering Monte Carlo Simulation technique. Porous structure of GNC models is evaluated by the method proposed by Bhattacharya and Gubbins. All the studied structures are strictly microporous. Next, mechanisms of Ar adsorption are described basing on the analysis of adsorption isotherms, enthalpy plots, the values of Henry's constants, $\alpha_{\mathrm{s}}$ and adsorption potential distribution plots. It is concluded that below pore diameters ca. $0.8 \mathrm{~nm}$, primary micropore filling process dominates. For structures possessing larger micropores, primary and secondary micropore filling mechanism is observed. Finally, the separation properties of $\mathrm{GNC}$ toward $\mathrm{CO}_{2} / \mathrm{CH}_{4}, \mathrm{CO}_{2} / \mathrm{N}_{2}$, and $\mathrm{CH}_{4} / \mathrm{N}_{2}$ mixtures are discussed and compared with separation properties of Virtual Porous Carbon models. GNCs may be considered as potential adsorbents for gas mixture separation, having separation efficiency similar or even higher than activated carbons with similar diameters of pores.
\end{abstract}

Key words: gyroidal nanoporous carbons, adsorption, gas mixtures separation, Monte Carlo simulations

PACS: 05.10.Ln, 05.70.-a, 51.10.+y, 51.30. $+i, 64.75 .+g$

\section{Introduction}

Adsorption of gas mixtures on solid surfaces has been attracting great interest for many years [1-7]. In the last decades there has been observed an increased interest to the development of new separation and purification techniques. It is evident that adsorption using various adsorbents is still a versatile tool for these purposes. On the other hand, the basic problem appearing in experimental studies is caused by difficulties in the synthesis of nanomaterials possessing desired properties. It is still not simple to control porosity and/or the chemical nature of the surface, and the both parameters at the same time. Moreover, experimental data on mixed systems are very limited, i.e., in the case of mixtures consisting of two volatile components the problem of the surface coverage determination has not been fully solved yet. Predicting adsorption behaviour of mixtures from pure component data is very important, from both the theoretical and practical viewpoints [8,-14]. It is well known that the theoretical calculations provide additional opportunities for studies to better understand the separation processes. However, despite the intensive experimental and theoretical studies, our knowledge of the properties and the structure of mixed adsorbed layers is rather sparse, especially, on new generations of nanoporous adsorbents.

Computer simulation is an efficient method for resolving the above mentioned problems, since it is capable of modelling the processes of interest at the required level of detail in a controllable environment, providing the necessary tools for establishing the connections between the observed phenomena

\footnotetext{
${ }^{*}$ This paper is dedicated to Prof. Stefan Sokołowski on the occasion of his 65th birthday.
} 
and their molecular-level physical background. Prof. Sokołowski’s (and co-workers) research topics of interest have also been concerned with the issue of mixtures using Monte Carlo simulations [15,-22], Density Functional Theory [23] 28], and Dissipative Particle Dynamics [29]. Their inspiring articles discuss, for example, the following problems: (i) adsorption from mixtures of monomers [15], dimers [15], the chain molecules [30,31], and even polymer mixtures [27], (ii) adsorption from mixtures on homogeneous [25, 32] and heterogeneous surfaces [15, 33 34], (iii) layering transition, capillary condensation, wetting phenomena, and multilayer adsorption of binary ideal mixtures, systems exhibiting negative deviations from ideal mixing or positive one, binary mixture with partially miscible components, etc. [16. 17 3438], (iv) interaction of charged chain particles and spherical counterions in contact with charged hard wall [31], (v) analysis of the properties of two-dimensional symmetrical mixtures in an external field of square symmetry [39, 40], (vi) demixing and freezing in two-dimensional symmetrical mixtures [21], and (vii) the behaviour of mixed two component submonolayer films ( $\mathrm{Ar}$ and $\mathrm{Kr}$ [41 42] or $\mathrm{Kr}$ and $\mathrm{Xe}$ [22] on graphite). The majority of the analysed adsorbents have an ideal geometry of pores, for example a slit-like [25, 26, 32, 34, 43]. However, more complex models have also been studied, for example, pillared slit-like pores [28] and slit-like pores with walls decorated by tethered polymer brushes in the form of stripes [29].

In the last decades, novel exotic porous carbon nanostructures (such as carbon nanotubes (CNTs), single-walled carbon nanohorns, graphene and graphitic nanoribbons, ordered porous carbons, wormlike nanotubes and graphitic nanofibers, stacked-cup carbon nanofibers, cubic carbon allotropes, carbon onions, carbyne networks, and others) have been projected to be among the most useful materials for selective adsorption and separation of fluid mixtures [44-48]. However, in the theoretical studies, different carbon adsorbents are studied, such as: carbon nanotubes [13, 49, 53], carbon nanohorns [13, 51, 54], 2D and 3D ordered carbon networks [55], hydrophobic virtual porous carbons (VPCs) [12 14 56, 62], oxidized VPCs [12, 14, 60, 62, 63], and triply periodic carbon minimal surfaces (Schwarz's primitive and Schoen's gyroid) [45, 59 64-70]. Recently, scientists have paid attention to the next generation of porous carbon molecular sieves materials, i.e., crystalline exotic cubic carbon allotropes: cubic carbon polymorphs (CCPs) [45 71-73], diamond-like super structures of CNTs (super diamonds) [74], diamond-like frameworks [75], porous aromatic frameworks (PAFs) [76, 77], diamond-like carbon frameworks (i.e., diamondynes, also named D-carbons) [78], tetrahedral node diamondyne [79], carbon allotropes proposed by Karfunkel and Dressler [45 80], compressed carbon nanotubes [45, 81], sodalite-like nanostructures [45. 82], folding of graphene slit-like pore walls [52 83], gyroidal nanoporous and mesoporous carbons (GNCs and GMCs, respectively) [84-86].

One of the most interesting and promising adsorbent from the above mentioned is GNC. In the current study, we consider nine different GNC structures having surface built in a way ensuring connection of each carbon atom with exactly three neighbours, similarly as "schwarzites". Nicolaï et al. [84] confirmed that the curvature and the rigidity do not play a crucial role in the performance of GNC structures for ionic conduction. The major role, however, is played by the pore size and pore volume. Indeed, the larger the pore is, the larger is the ionic transport. Finally, the mentioned authors stated that GNC structures with tunable properties can be widely applied to water filtration or energy storage.

\section{Simulation details}

We used the structures of nine gyroidal nanocarbons (denoted as GNC-04, GNC-07, GNC-09, GNC-11, GNC-12, GNC-13, GNC-15, GNC-18 and GNC-21) published previously by Nicolaï et al. [84] (see figure 1 in [84]). In the case of the first six systems, original boxes generated by Nicolaï et al. [84] were multiplied (eightfold) in order to obtain box size at least two times greater than the cut-off distances used during simulations described below. The porosity of all the studied carbonaceous adsorbents was characterised by a geometrical method proposed by Bhattacharya and Gubbins (BG) [87. The implementation of the method was described in detail elsewhere [88, 89]. The BG method provided histograms of pore sizes (effective diameters $-d_{\text {eff }}$ ). These data were also used to calculate the average sizes of pores accessible for Ar atoms ( $d_{\text {eff,acc,av }}$ [ [88]. In addition, the volume of pores accessible for Ar was determined using a combination of the BG method and Monte Carlo integration [88.

Argon adsorption isotherms at its boiling point (i.e., $T=87 \mathrm{~K}$ ) on all the studied nanocarbons were 
simulated using the hyper parallel tempering Monte Carlo method (HPTMC) proposed by Yan and de Pablo [90]. The simulation scheme was the same as in previous work [88]. We considered 93 replicas corresponding to different relative pressure values $\left(p / p_{\mathrm{s}}\right.$, where $p$ and $p_{\mathrm{s}}$ are equilibrium and saturated Ar vapour pressure, respectively) in the range $1.0 \times 10^{-10}-1.0$. Other details of the performed HPTMC simulations are described in [88]. The average numbers of Ar atoms in the simulation box were used to calculate the adsorption amount of Ar per unit of mass of the adsorbent $(a)$ [88]. The isosteric enthalpy of adsorption $\left(q^{\text {st }}\right)$ was also determined from the theory of fluctuations [88 91] to reflect the energetics of the process.

In order to analyse the mechanism of Ar adsorption, we constructed high resolution $\alpha_{\mathrm{s}}$-plots [92] based on simulated adsorption isotherms. We used Ar adsorption isotherm simulated in the ideal slitlike system composed of graphene sheets with effective pore width equal to $10 \mathrm{~nm}$ as the reference one. We also determined the values of Henry's constant $\left(K_{\mathrm{H}}\right)$ from the slope of the linear part of adsorption isotherms in the low-pressure range [83]. Finally, adsorption potential distribution (APD) curves [93.95] were calculated. The APD curve is the first derivative of the so-called characteristic curve, presenting adsorption amount as a function of the adsorption potential $\left(A_{\mathrm{pot}}\right)$ defined as:

$$
A_{\mathrm{pot}}=-R T \ln \frac{p}{p_{\mathrm{s}}}
$$

where $R$ is the universal gas constant. The differentiation was performed numerically by the approximation of the isotherms using some empirical functions and calculating their derivatives.

We also simulated the adsorption and separation of three binary gas mixtures (important from practical point of view): $\mathrm{CO}_{2} / \mathrm{CH}_{4}, \mathrm{CO}_{2} / \mathrm{N}_{2}$, and $\mathrm{CH}_{4} / \mathrm{N}_{2}$ on all the studied GNCs. The computations were performed for $T=298 \mathrm{~K}$ using the grand canonical Monte Carlo method (GCMC) [91 96]. The simulation scheme was the same as in our previous works 60 62]. Simulations were performed for the total mixture pressure $p_{\text {tot }}=0.1 \mathrm{MPa}$ (i.e., atmospheric pressure) and for the following mole fractions of components in the gaseous phase $(y): 0.0,0.01,0.025,0.05,0.1,0.2,0.3,0.4,0.5,0.6,0.7,0.8,0.9,0.95,0.975,0.99$, and
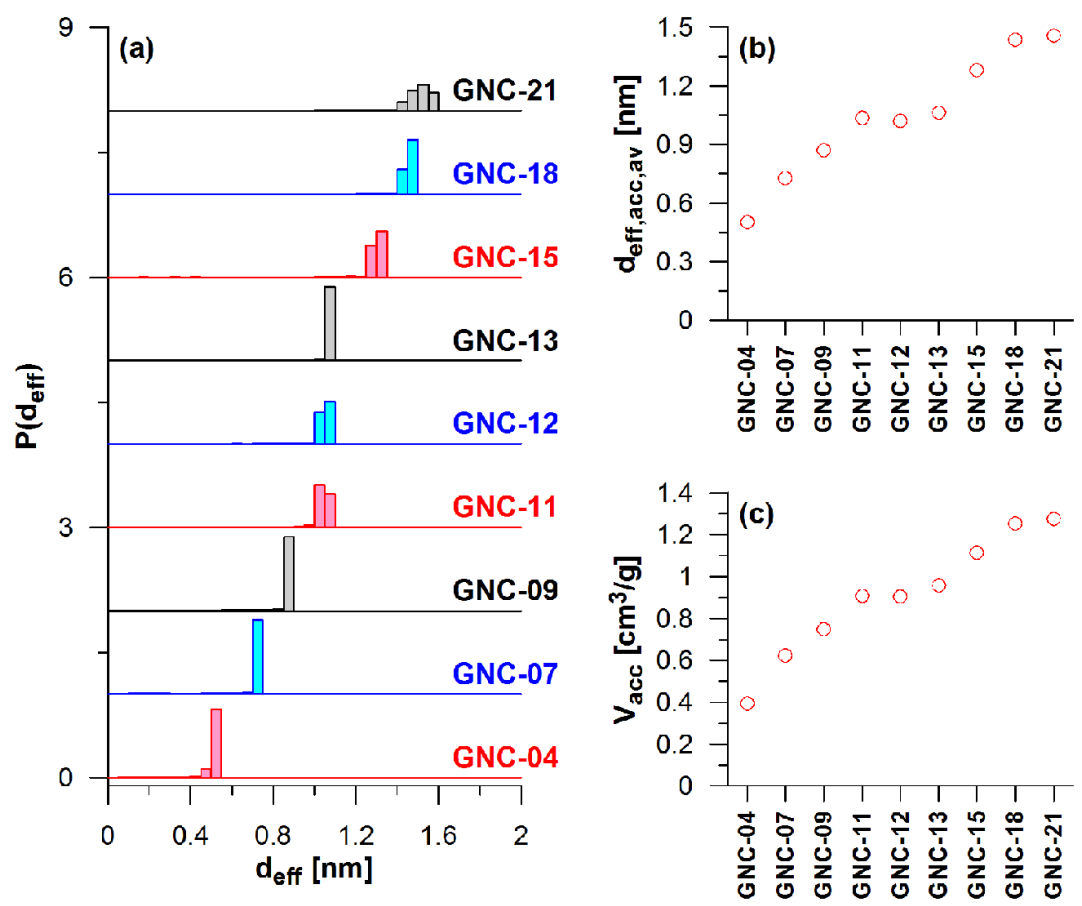

Figure 1. (Color online) Comparison of (a) pore size histograms for all the studied nanocarbons determined from the BG method (the subsequent histograms are shifted by 1 unit from the previous ones), (b) average sizes and (c) volume of pores accessible for Ar atoms, respectively. 
1.0. For each point, the mole fractions of components in the adsorbed phase $(x)$ were calculated from the average numbers of molecules present in the simulation box. The efficiency of the process of separation of mixtures was reflected by the value of equilibrium separation factor (the $1^{\text {st }}$ component over the $2^{\text {nd }}$ one):

$$
S_{1 / 2}=\frac{x_{1} / x_{2}}{y_{1} / y_{2}}
$$

The adsorbed phase is enriched in the $1^{\text {st }}$ component if $S_{1 / 2}>1$.

\section{Results and discussion}

Figure 1 (a) collects histograms of effective pore sizes, determined from the application of BG method, for all the studied GNCs. All the structures are strictly microporous, i.e., the diameters of pores do not exceed $2 \mathrm{~nm}$. Generally, the size of dominant pores increases in the considered series (from the GNC04 up to GNC-21). However, there are two groups of nanocarbons having similar diameters of the main pores: (i) GNC-11, GNC-12 and GNC-13 $-d_{\text {eff }}$ around $1 \mathrm{~nm}$ and (ii) GNC-18 and GNC-21 $-d_{\text {eff }}$ around $1.5 \mathrm{~nm}$. It should be noted that in the case of GNC-21, some amount of pores wider than in GNC-18 is also present. These regularities are reflected by the values of the average pore diameter [figure 1 (b)]. The increase in pore diameters is accomplished by the increase in pore volume from ca. $0.4 \mathrm{~cm}^{3} / \mathrm{g}$ for GNC-04 up to ca. $1.3 \mathrm{~cm}^{3} / \mathrm{g}$ for GNC-18 and GNC-21 [figure 1 (c)].

Figure 2 shows the comparison of Ar adsorption isotherms simulated for all the studied GNCs. The

GNC-04
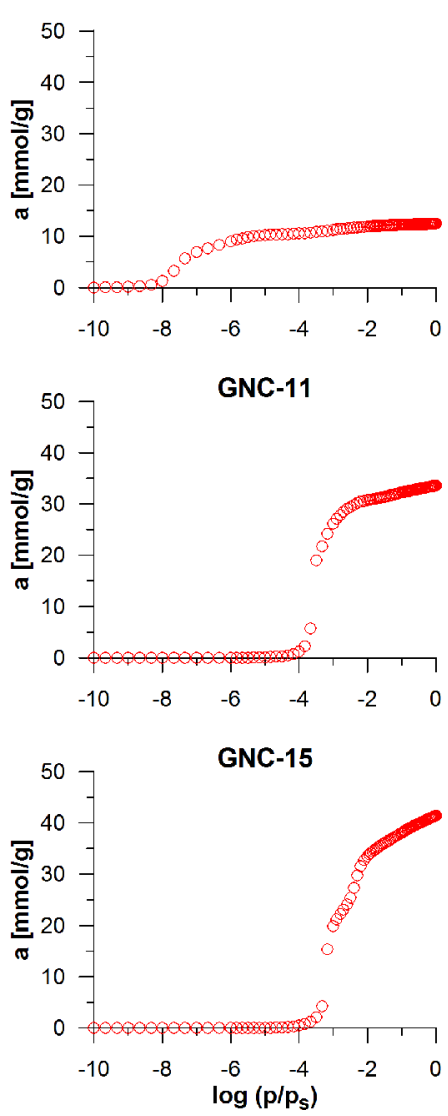

GNC-07

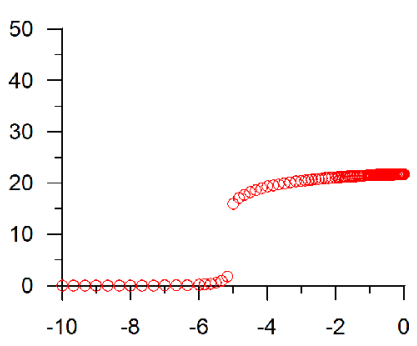

GNC-12

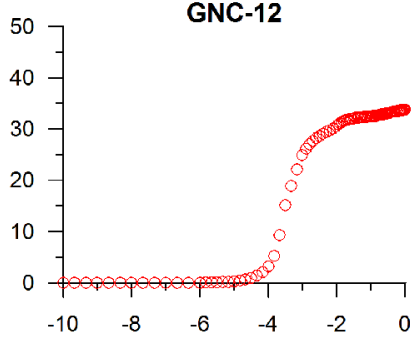

GNC-18

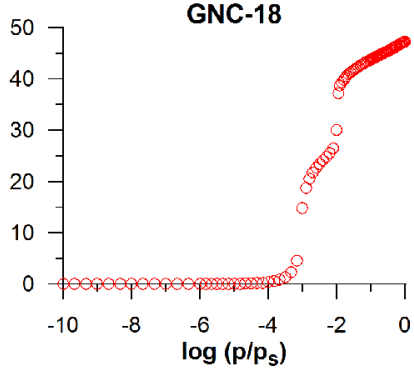

GNC-09

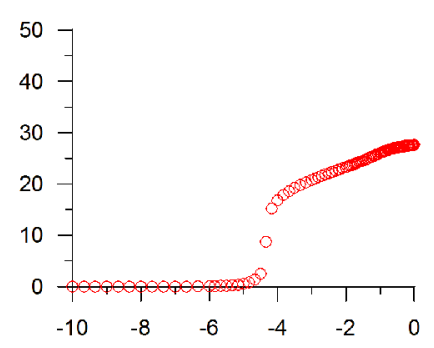

GNC-13

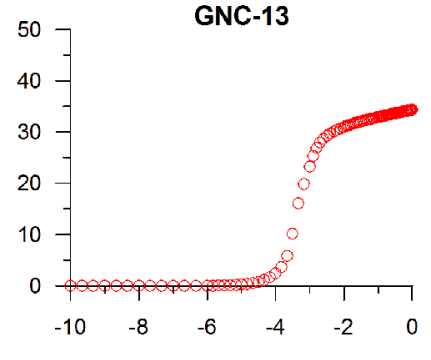

GNC-21

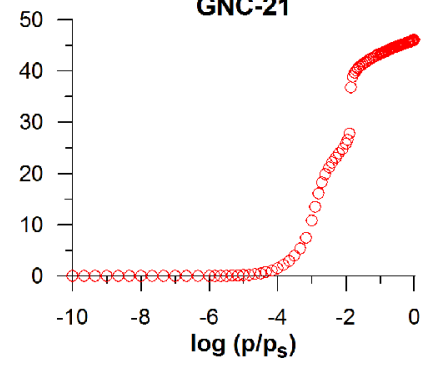

Figure 2. (Color online) Comparison of Ar adsorption isotherms $(T=87 \mathrm{~K})$ simulated for all the considered nanocarbons. 


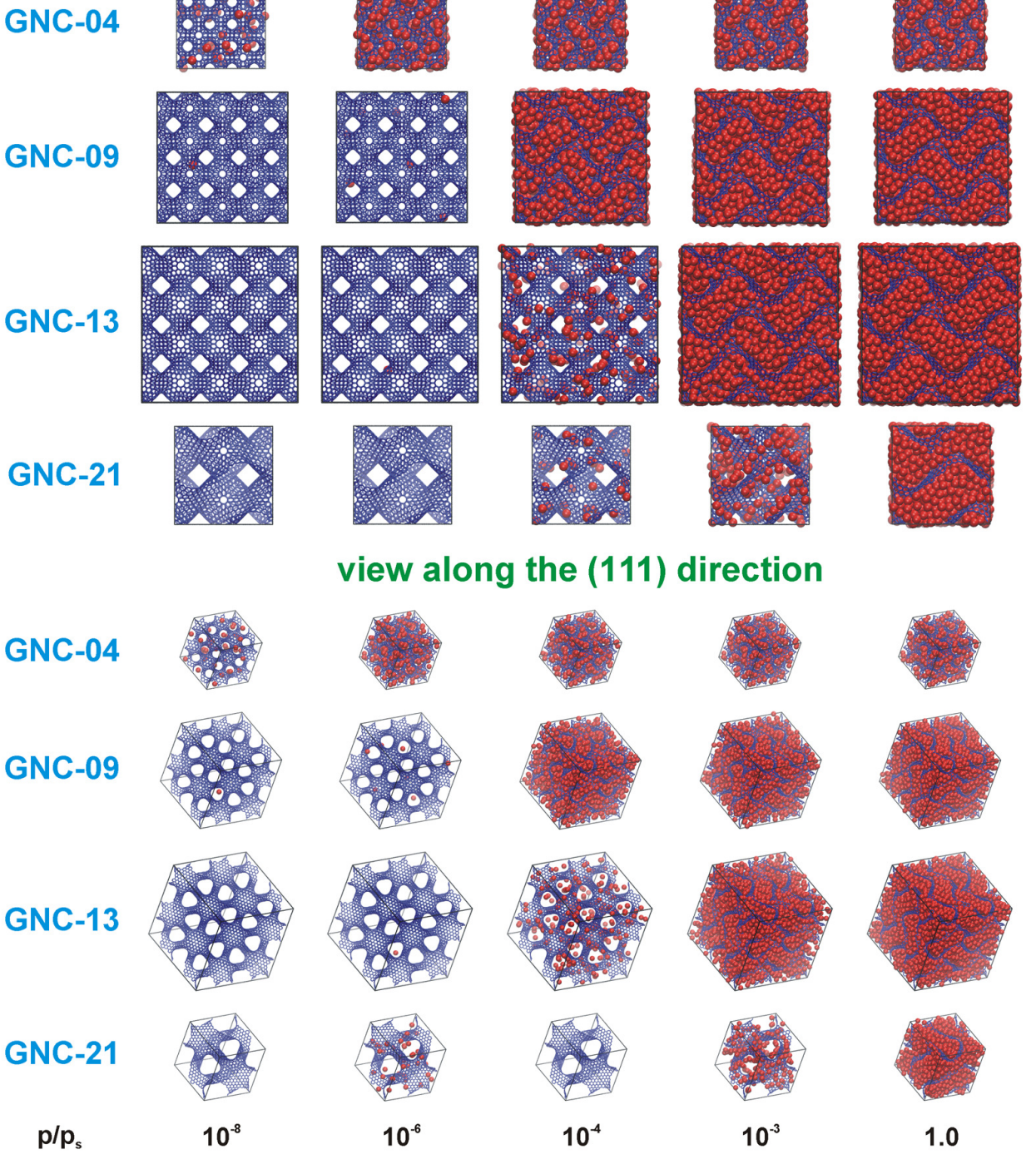

Figure 3. (Color online) Equilibrium argon configurations for selected nanocarbons and selected values of relative pressure (the frames reflect the size of simulation boxes, all the structures are in the same scale). It should be noted that this figure was created using the VMD program [97].

changes observed in the shape of isotherms reflect the differences in the properties of nanocarbons. Adsorption capacity varies from ca. $12 \mathrm{mmol} / \mathrm{g}$ for GNC-04 up to ca. $45 \mathrm{mmol} / \mathrm{g}$ for GNC-18 and GNC-21. These changes correspond to the differences in the pore volume [figure 1(c)]. At the same time, the shift of the pore filling pressure toward higher values is observed. The pores of the GNC-04 structure are filled in the relative pressure range $10^{-8}-10^{-6}$. However, the total filling of GNC-18 and GNC-21 occurs for similar values of relative pressure (around $10^{-2}$ ). The middle carbons of the series (i.e., GNC-11, GNC-12 and GNC-13) are filled in the similar range of relative pressure $\left(p / p_{\mathrm{s}}>10^{-4}\right)$. The differences in the pore filling are also clearly seen on equilibrium snapshots of Ar configurations in the simulation boxes shown in figure 3 These regularities are related to the differences in diameters of dominant pores present in the individual GNCs [figure 1 (a)]. Finally, one can observe that in the case of initial structures (up to GNC-13), the pore filling is a single-step process. However, the pores of GNC-15, GNC-18 and GNC-21 are filled in two steps. This is also caused by the rise in pore sizes. For pores wider than $1 \mathrm{~nm}$, in the first step 
GNC-04

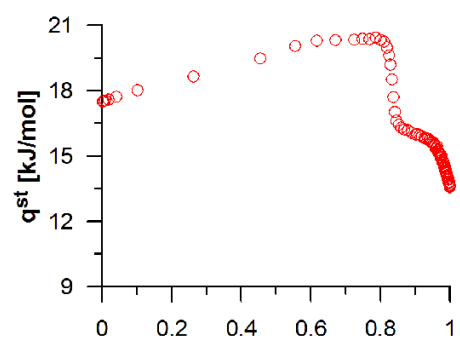

GNC-11
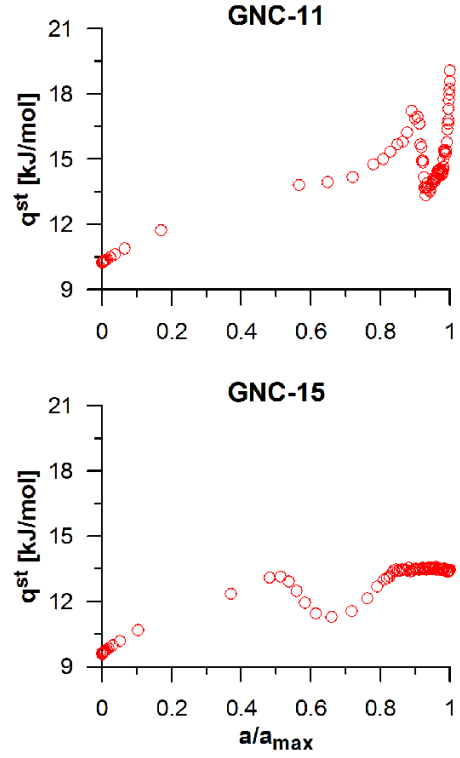

GNC-07

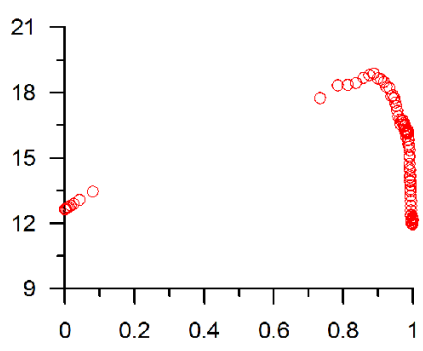

GNC-12

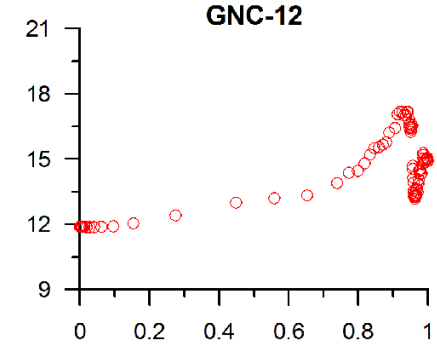

GNC-18

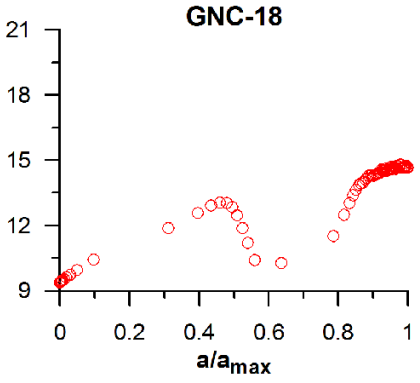

GNC-09

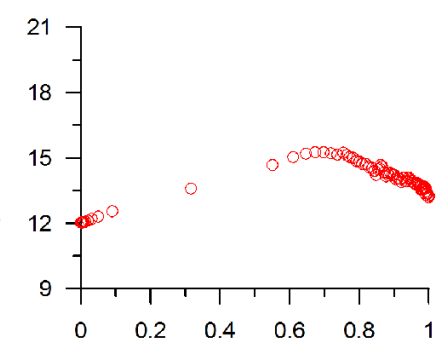

GNC-13

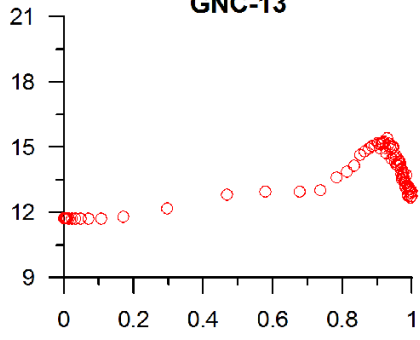

GNC-21

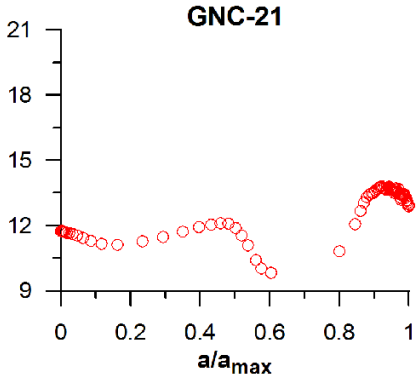

Figure 4. (Color online) Comparison of isosteric enthalpy of Ar adsorption [the data related to figure 2 for clarity adsorption amounts are normalised by the maximum observed value $\left.\left(a_{\max }\right)\right]$.

a monolayer is formed and next the remaining free volume is filled.

Figure 4 shows the plots of isosteric enthalpy of adsorption related to the isotherms shown in figure 2 For low loadings, the $q^{\text {st }}$ values increase as the adsorption amount rises. In this range, Ar atoms are adsorbed mainly on high-energetic centres. The increasing adsorption amount causes other Ar atoms to appear in the vicinity of the initially adsorbed ones. This rises the contribution of fluid-fluid interactions to the total energy of a system. Here, the only exception is GNC-21 structure. There is observed a decrease in $q^{\text {st }}$ for relative adsorption up to ca. 0.1. This system has probably got a heterogeneous surface. Consequently, the subsequent Ar atoms are adsorbed on centres having lower energy and this reduces the effects of the increase in lateral Ar-Ar interactions. In the intermediate range of adsorption, the enthalpy rises for all the structures until the entire adsorbent surface is covered. Next, the values of $q^{\text {st }}$ decrease since $\mathrm{Ar}$ is adsorbed at the places more distant from the surface and this is connected with lower solidfluid contributions. In the case of the structures having the widest pores (especially GNC-15, GNC-18 and GNC-21), the second peak on $q^{\text {st }}$ is also observed. This peak is related to the total filling of pores.

Comparing the enthalpy at zero coverage for all the systems, one can observe that GNC-04 has a remarkably higher value of this parameter (ca. $17.5 \mathrm{~kJ} / \mathrm{mol}$ ) than the other systems. This is connected with the presence of the narrowest pores having high adsorption energy. The other structures may be divided into two groups. The first one includes GNC-07, GNC-09, GNC-12, GNC-13 and GNC-21 carbons. In this case, the enthalpy at zero coverage is close to $12 \mathrm{~kJ} / \mathrm{mol}$. For the second group (GNC-11, GNC-15 and GNC-18), this enthalpy value is in the range $9-10 \mathrm{~kJ} / \mathrm{mol}$. This may suggest some similarities in the surface nature of the group members (for example curvature, which is the main factor determining the energy of adsorption on the surface). The above-described differences in the energy of interactions with the surface of 


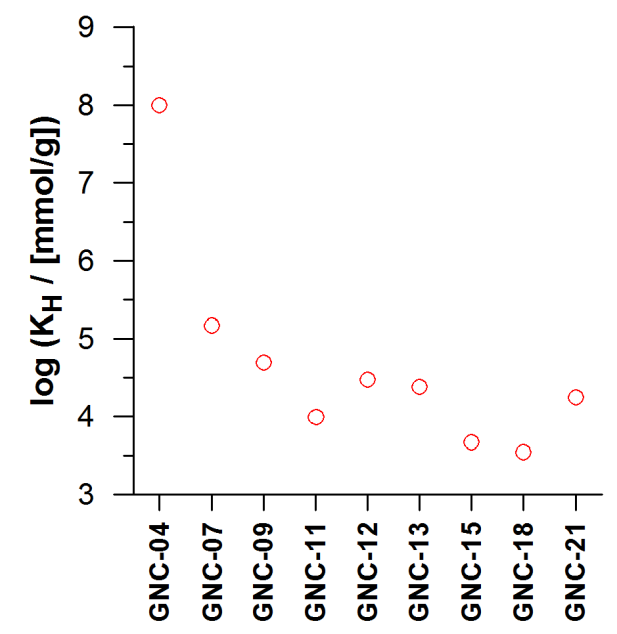

Figure 5. (Color online) Comparison of Henry's constants related to the Ar adsorption isotherms presented on figure 2
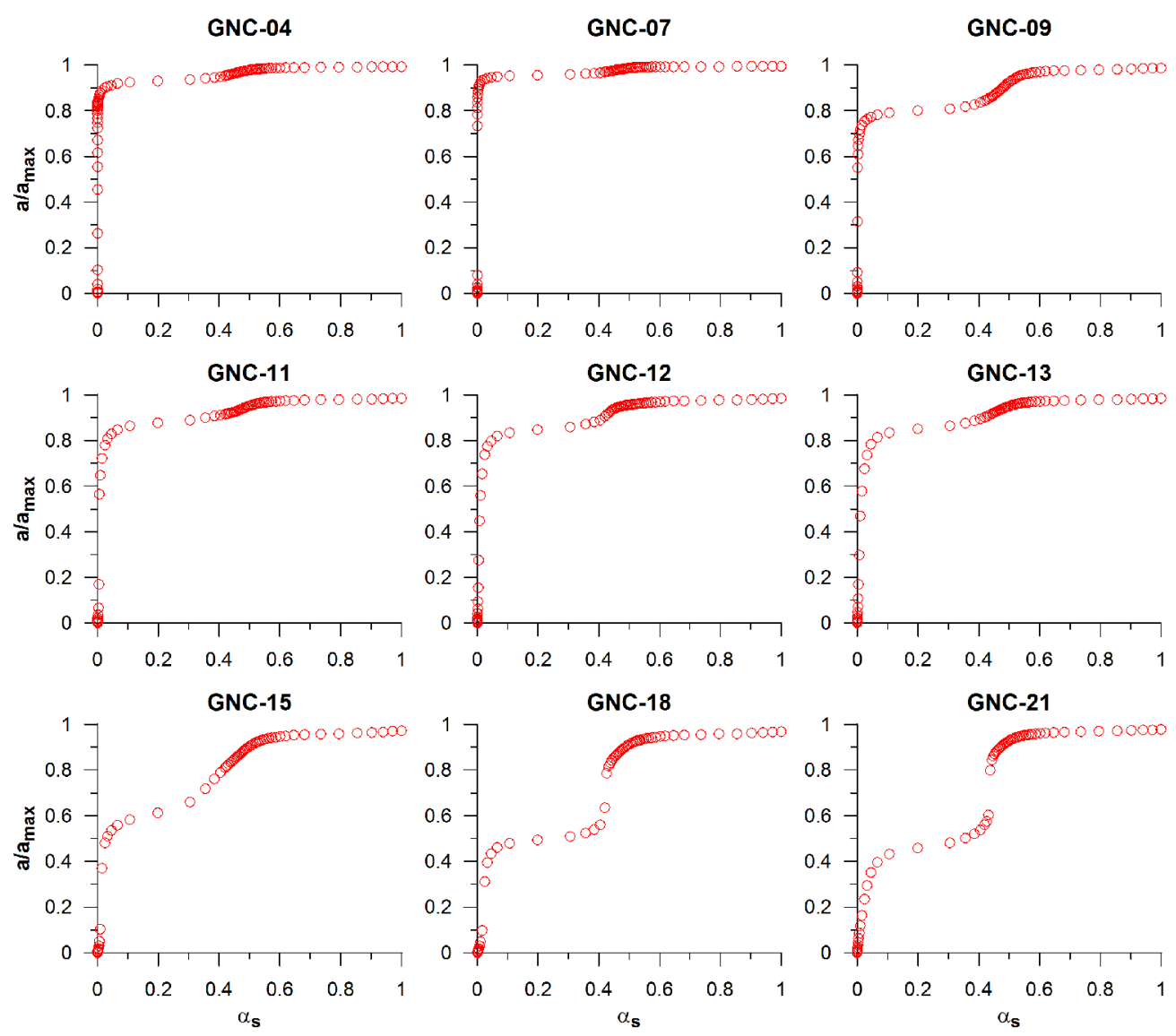

Figure 6. (Color online) Comparison of $\alpha_{\mathrm{s}}$-plots related to the Ar adsorption isotherms presented in figure 2 [for clarity the adsorption amounts are normalized by the maximum observed value $\left(a_{\max }\right)$ ]. The $\alpha_{\mathrm{s}}$ is the normalized adsorption on the reference material, i.e., in the ideal slit-like system with the effective pore width equal to $10 \mathrm{~nm}$. 

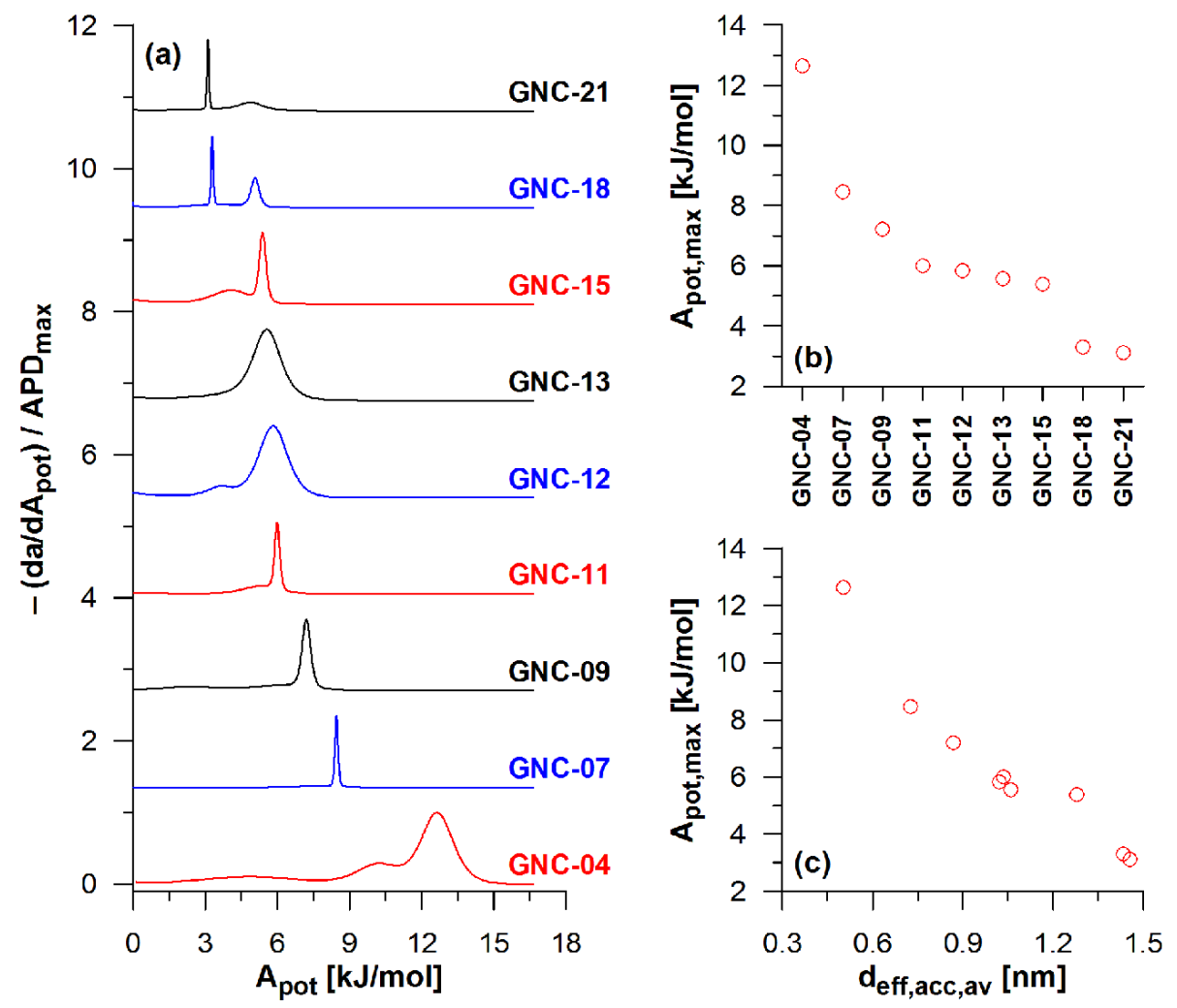

Figure 7. (Color online) (a) Comparison of APD curves [for clarity, all the curves are normalized by the maximum observed value ( $\left(\mathrm{APD}_{\max }\right)$; subsequent curves are shifted by 1.35 units]. (b) Location of the main peak on the APD curves $\left(A_{\text {pot,max }}\right)$. (c) Correlation between the location of the main peak and the average sizes of pores accessible for Ar atoms.

adsorbents fully correspond to the variation of Henry's constants shown in figure 5 This is not surprising since solid-fluid interactions are the main factor affecting the shape of the isotherm in the low pressure range. Hence, the value of $K_{\mathrm{H}}$ for GNC-04 system is at least 1000 times greater than for the other ones. For three of the remaining structures (i.e., GNC-11, GNC-15 and GNC-18), lower values of $K_{\mathrm{H}}\left(<10^{4} \mathrm{mmol} / \mathrm{g}\right)$ are recorded. The same carbons have the lowest enthalpy of adsorption at zero coverage.

Figure 6 presents comparison of $\alpha_{\mathrm{s}}$-plots related to the Ar adsorption isotherms. One can see that the adsorption process is dominated by a FS swings (GNC-04 and GNC-07) and the FS-CS swings (remaining structures) [98]. It can be noticed that with the rise in the pore diameter, the combination of primary and secondary micropore filling mechanism occurs. The boundary between those mechanisms is located for the structures with pore diameters around ca. $0.8 \mathrm{~nm}$. It is also interesting that the range on $\alpha_{\mathrm{s}}$-plots connecting FS and CS swings is not linear as it is observed for the case of slit-like carbon micropores. This can be caused by the surface curvature.

Figure 7 (a) compares APD curves for all the systems studied. The presented data are complementary to adsorption isotherms shown in figure 2. On all the APD curves, at least one (dominant) peak is observed. It corresponds to the pore filling. Its location $\left[A_{\text {pot,max }}\right.$, figure 7 (b)] is related to the pressure of the pore filling according to equation 2.1. Hence, this parameter may be correlated with the size of pores - see figure 7 (c). This figure quantitatively confirms the above-described qualitative differences in the pore filling process. The width of the main peak also provides some information on the process. The narrow peak means that condensation occurs in a narrow range of relative pressure. By contrast, a wide peak denotes a wide condensation range. For example, the pore filling in GNC-04 system occurs, as mentioned above, for $10^{-8}<p / p_{\mathrm{s}}<10^{-6}$ and this is reflected by a wide peak with the maximum located at ca. $12.6 \mathrm{~kJ} / \mathrm{mol}$. For this system, the other two peaks are also observed (the third one with the maximum 

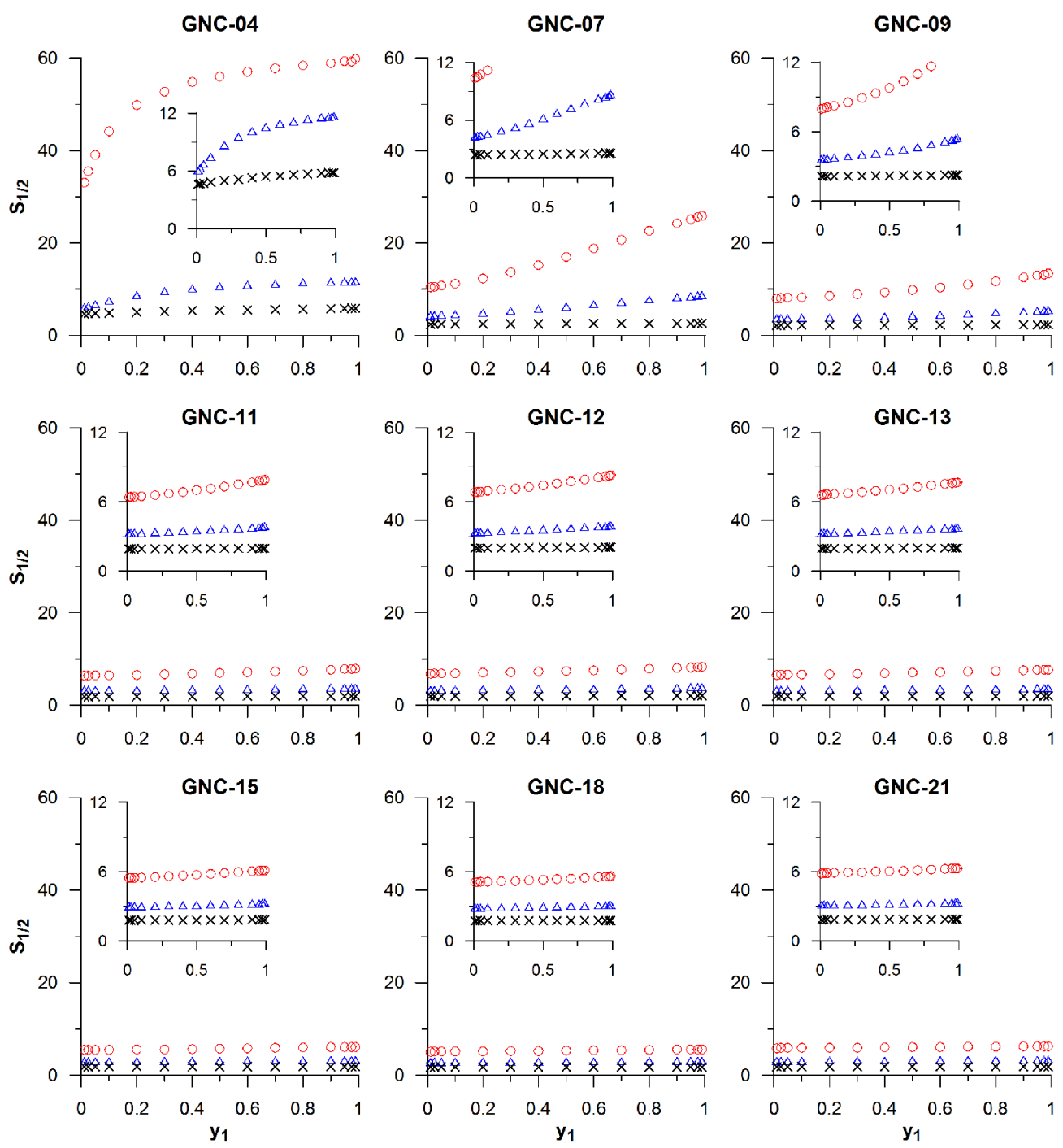

$$
\triangle \mathrm{CO}_{2} / \mathrm{CH}_{4} \bigcirc \mathrm{CO}_{2} / \mathrm{N}_{2} \times \mathrm{CH}_{4} / \mathrm{N}_{2}
$$

Figure 8. (Color online) Comparison of equilibrium separation factors $\left[S_{1 / 2}\right.$, equation [2.2] $]$ for the adsorption of all the mixtures $\left(T=298 \mathrm{~K}, p_{\text {tot }}=0.1 \mathrm{MPa}\right.$ ) on all the nanocarbons studied. The data plotted as the function of the $1^{\text {st }}$ component mol fraction in the gaseous phase ( $y_{1}$, the $1^{\text {st }}$ component is $\mathrm{CO}_{2}$ for $\mathrm{CO}_{2} / \mathrm{CH}_{4}$ and $\mathrm{CO}_{2} / \mathrm{N}_{2}$ mixtures and $\mathrm{CH}_{4}$ for $\mathrm{CH}_{4} / \mathrm{N}_{2}$ mixture).

at ca. $45 \mathrm{~kJ} / \mathrm{mol}$ is very broad). These peaks reflect the other sub-steps of the Ar density rise in pores of this structure. Similar interpretation also concerns the additional peaks observed for GNC-11 and GNC-12. In the case of GNC-18 and GNC-21 structures, the observed second peak is related to the above mentioned monolayer formation. A slightly different scenario occurs for GNC-15 carbon. Here, the dominant peak is connected with the monolayer formation and the second low (also wide) peak reflects the filling of the remaining pore volume. This fact explains why the location of the main peak for this structure deviates from the distinct trend visible for all the other GNCs in correlation shown in figure 7 (c).

Figure 8 presents a comparison of equilibrium separation factors for adsorption of all three studied mixtures for different compositions of gaseous phase. In addition, figure 9 directly compares the efficiency of separation of equimolar mixtures for all the studied systems. The separation is a consequence of differences in the adsorption of mixture components. Since the critical temperature for the studied gases decreases significantly in the sequence $\mathrm{CO}_{2}>\mathrm{CH}_{4}>\mathrm{N}_{2}$, the adsorption affinity decreases in the 

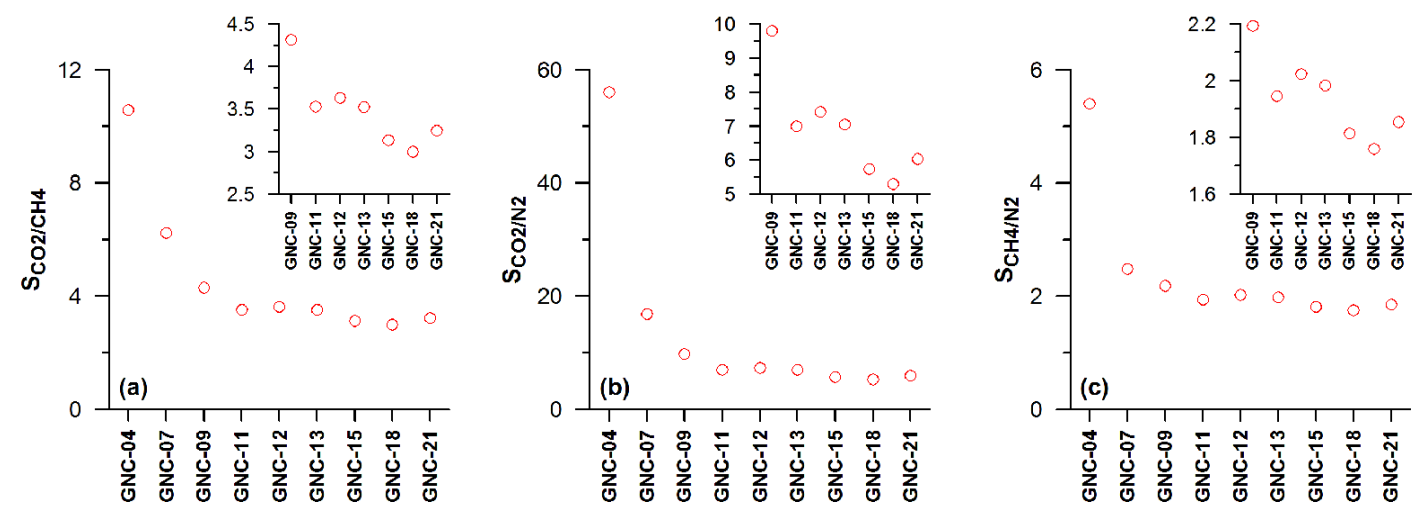

Figure 9. (Color online) Comparison of equilibrium separation factors for adsorption of equimolar ( $y=0.5$ ) mixtures: (a) $\mathrm{CO}_{2} / \mathrm{CH}_{4}$, (b) $\mathrm{CO}_{2} / \mathrm{N}_{2}$ and (c) $\mathrm{CH}_{4} / \mathrm{N}_{2}\left(p_{\text {tot }}=0.1 \mathrm{MPa}, T=298 \mathrm{~K}\right)-$ see figure 8

same sequence (for the subsequent gases, the process occurs for increasing value of reduced temperature). Consequently, for the given GNC, the highest equilibrium separation factor is observed for $\mathrm{CO}_{2} / \mathrm{N}_{2}$ and the smallest one for $\mathrm{CH}_{4} / \mathrm{N}_{2}$ mixture. The qualitative differences in separation efficiency between the structures studied are the same for all the mixtures studied. The highest values of equilibrium separation factor (remarkably higher than for the other systems) are observed for GNC-04 carbon. This is connected
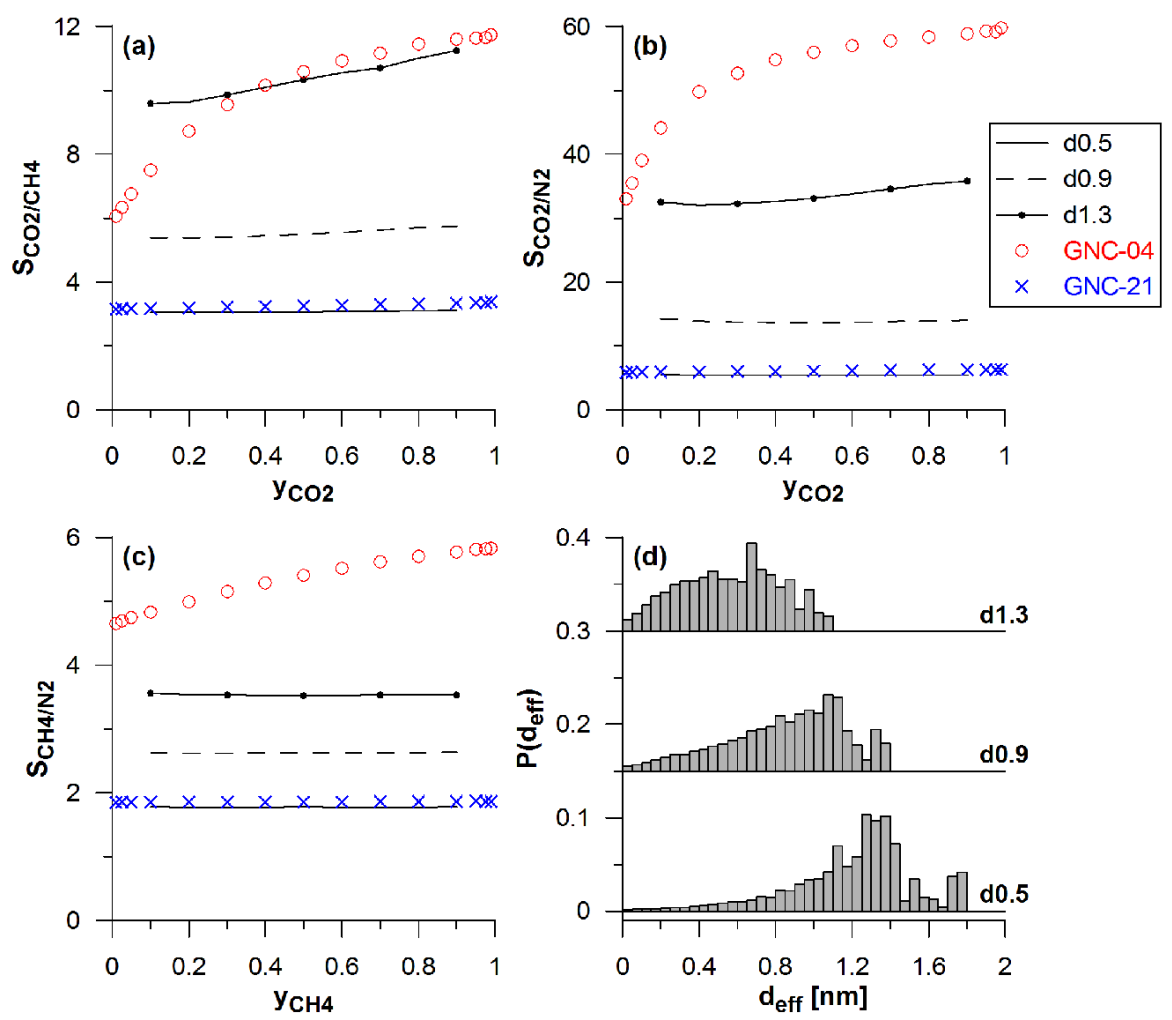

Figure 10. (Color online) Comparison of equilibrium separation factors [(a) $\mathrm{CO}_{2} / \mathrm{CH}_{4}$, (b) $\mathrm{CO}_{2} / \mathrm{N}_{2}$ and (c) $\mathrm{CH}_{4} / \mathrm{N}_{2}$ ] for mixture adsorption ( $p_{\text {tot }}=0.1 \mathrm{MPa}, T=298 \mathrm{~K}$ ) on GNC-04 and GNC-21 nanocrabons and on three virtual porous carbons (VPCs): $\mathrm{d} 0.5, \mathrm{~d} 0.9$ and $\mathrm{d} 1.3$ [88] (the data for VPCs taken from our previous paper [60]). In addition, panel (d) presents the pore size histograms for the presented VPCs [88] (the subsequent histograms are shifted by 0.15 units from the previous ones). 
with the presence of the narrowest pores. Among the other nanocarbons, GNC-07 and GNC-09 also exhibit higher values of $S_{1 / 2}$. However, they are lower than in the case of GNC-04 since these structures have wider pores. The efficiency of separation for the next GNCs is similar. Nevertheless, some small differences are also noticeable (see insets in figure 9). The GNC-11, GNC-15 and GNC-18 structures are less efficient in comparison with the adjacent carbons in the series. These regularities are analogous to that observed for Henry's constants shown in figure 5 and discussed above. These facts suggest that in the case of GNCs with pores wider than ca. $1 \mathrm{~nm}$, the main factor affecting the efficiency of the separation process is the energetics of fluid interaction with the curved surface of the nanocarbons studied.

Finally, figure 10 compares the equilibrium separation factors (all three mixtures studied) for GNC-04 and GNC-21 structures and for three virtual porous carbons (VPCs) described in detail previously [88] and having different porosity - see figure 10 (d). As one can see, the GNC-21 structure exhibits a separation efficiency similar to the d0.5 carbon. The main pores of both adsorbents have a similar width. However, this VPC has also some narrower micropores which presence probably positively affects the separation efficiency. Such micropores are absent in the case of GNC-21 and, nonetheless, this nanocarbon exhibits similar values of $S_{1 / 2}$. This is the consequence of the adsorption energetics on a curved surface of this structure. On the contrary, the GNC-04 nanocarbon exhibits the efficiency of the $\mathrm{CO}_{2} / \mathrm{CH}_{4}$ mixture separation similar to the $\mathrm{d} 1.3$ carbon. This VPC has micropores distributed in the range up to ca. $1 \mathrm{~nm}$ [figure 10 (d)]. A large part of them has diameters similar to or lower than the GNC-04 structure. In the case of $\mathrm{CO}_{2} / \mathrm{N}_{2}$ and $\mathrm{CH}_{4} / \mathrm{N}_{2}$ mixtures, the values of equilibrium separation factors for GNC-04 are higher than for d1.3 carbon. This comparison (especially for $\mathrm{CO}_{2} / \mathrm{CH}_{4}$ mixture - similar efficiency for both adsorbents and for $\mathrm{CH}_{4} / \mathrm{N}_{2}$ mixture - higher efficiency for GNC-04) may suggest that a regularly curved surface of gyroidal carbons exhibits higher affinity to $\mathrm{CH}_{4}$ molecules than a heterogeneous surface of activated carbons.

Summing up, the GNCs studied may be considered as potential adsorbents for gas mixture separation. The efficiency of this process is similar to or higher than for activated carbons with similar diameters of pores. The GNC-04 or similar structures seem to be quite promising materials for this purpose since this nanocarbon contains narrow and quite uniform pores (ca. $0.5 \mathrm{~nm}$ ).

\section{Conclusions}

Adsorption and separation properties of GNCs - a new class of exotic nanocarbon materials, are studied for the first time using computer simulation technique. All the structures studied are strictly microporous. The mechanisms of Ar adsorption are described basing on the analysis of adsorption isotherms, enthalpy plots, the values of Henry's constants, $\alpha_{\mathrm{s}}$ and adsorption potential distribution plots. Below the pore diameters ca. $0.8 \mathrm{~nm}$, primary micropore filling process dominates. For structures possessing larger micropores, primary and secondary micropore filling mechanisms are observed. GNCs may be considered as potential adsorbents for gas mixture separation, having separation efficiency similar to or higher than this for activated carbons with similar diameters of pores.

\section{Acknowledgements}

The authors acknowledge the use of the computer cluster at Poznań Supercomputing and Networking Centre (Poznań, Poland) as well as the Information and Communication Technology Centre of the Nicolaus Copernicus University (Toruń, Poland).

\section{References}

1. Gas Separation by Adsorption Processes, Series on Chemical Engineering Vol. 1, Yang R.T. (Ed.), Imperial College Press, London, 1997.

2. Ruthven D.M., Farooq S., Knaebel K.S., Pressure Swing Adsorption, Wiley-VCH, New York, 1994.

3. Sinaiski E.G., Lapiga E.J., Separation of Multiphase, Multicomponent Systems, Wiley-VCH, Weinheim, 1997.

4. Jaroniec M., Madey R., Physical Adsorption on Heterogeneous Solids, Elsevier, New York, 1988. 
5. Rudziński W., Everett D.H., Adsorption of Gases on Heterogeneous Surfaces, Academic Press, New York, 1992.

6. Rouquerol F., Rouquerol J., Sing K.S.W., Llewellyn P., Maurin G., Adsorption by Powders and Porous Solids. Principles, Methodology and Applications, 2nd Edn., Elsevier, Amsterdam, 2014; doi 10.1016/B978-0-08-097035-6.09991-5.

7. Bansal R.C., Goyal M., Activated Carbon Adsorption, CRC Press, Boca Raton, 2005.

8. Palmer J.C., Moore M.V., Roussel T.J., Brennan J.K., Gubbins K.E., Phys. Chem. Chem. Phys., 2011, 13, 3985; doi $10.1039 / \mathrm{c} 0 \mathrm{cp} 02281 \mathrm{k}$

9. Liu L., Nicholson D., Bhatia S.K., J. Phys. Chem. C, 2015, 119, 407; doi 10.1021/jp5099987.

10. Ozturk T.N., Keskin S., Ind. Eng. Chem. Res., 2013, 52, 17627; doi 10.1021/ie403159c

11. Lu X., Jin D., Wei S., Wang Z., An C., Guo W., J. Mater. Chem. A, 2015, 3, 12118; doi/10.1039/C4TA06829G

12. Billemont P., Coasne B., De Weireld G., Adsorption, 2014, 20, 453; doi $10.1007 / \mathrm{s} 10450-013-9570-\mathrm{Z}$

13. Furmaniak S., Terzyk A.P., Kaneko K., Gauden P.A., Kowalczyk P., Ohba T., Chem. Phys. Lett., 2014, 595-596, 67; doi $10.1016 /$ j.cplett.2014.01.031

14. Di Biase E., Sarkisov L., Carbon, 2015, 94, 27; doi 10.1016/j.carbon.2015.06.056

15. Borówko M., Patrykiejew A., Rżysko W., Sokołowski S., Langmuir, 1997, 13, 1073; doi 10.1021/la950940a.

16. Grabowski K., Patrykiejew A., Sokołowski S., Thin Solid Films, 1999, 352, 259; doi 10.1016/S0040-6090(99)00291-6

17. Grabowski K., Patrykiejew A., Sokołowski S., Thin Solid Films, 2000, 379, 297; doi 10.1016/S0040-6090(00)01398-5

18. Patrykiejew A., Sałamacha L., Sokołowski S., Pizio O., Phys. Rev. E, 2003, 67, 061603; doi 10.1103/PhysRevE.67.061603

19. Patrykiejew A., Sałamacha L., Sokołowski S., Dominguez H., Pizio O., Phys. Rev. E, 2003, 67, 031202; doi 10.1103/PhysRevE.67.031202

20. Patrykiejew A., Sokołowski S., Pizio O., J. Phys. Chem. B, 2005, 109, 14227; doi 10.1021/jp048170b

21. Patrykiejew A., Sokołowski S., Phys. Rev. E, 2010, 81, 012501; doi 10.1103/PhysRevE.81.012501

22. Patrykiejew A., Sokołowski S., J. Chem. Phys., 2012, 136, 144702; doi 10.1063/1.3699330

23. Bryk P., Sokołowski S., Pizio O., J. Phys. Chem. B, 1999, 103, 3366; doi 10.1021/jp982028r

24. Noworyta J.P., Henderson D., Sokołowski S., Chan K.-Y., Mol. Phys., 1998, 95, 415; doi 10.1080/00268979809483175

25. Patrykiejew A., Pizio O., Pusztai L., Sokołowski S., Mol. Phys., 2003, 101, 2219; doi 10.1080/0026897031000099925

26. Patrykiejew A., Pizio O., Sokołowski S., Sokołowska Z., Phys. Rev. E, 2004, 69, 061605; doi 10.1103/PhysRevE.69.061605

27. Bryk P., Sokołowski S., J. Chem. Phys., 2004, 120, 8299; doi $10.1063 / 1.1695554$

28. Pizio O., Sokołowski S., Sokołowska Z., J. Chem. Phys., 2011, 134, 214702; doi 10.1063/1.3597773

29. Ilnytskyi J.M., Patsahan T., Sokołowski S., J. Chem. Phys., 2011, 134, 204903; doi 10.1063/1.3592562

30. Bryk P., Pizio O., Sokołowski S., J. Chem. Phys., 2005, 122, 174906; doi 10.1063/1.1888425

31. Pizio O., Bucior K., Patrykiejew A., Sokołowski S., J. Chem. Phys., 2005, 123, 214902; doi 10.1063/1.2128701

32. Sokołowski S., Rżysko W., Pizio O., J. Colloid Interface Sci., 1999, 218, 341; doi 10.1006/jcis.1999.6392

33. Kruk M., Patrykiejew A., Sokołowski S., Surf. Sci., 1995, 340, 179; doi 10.1016/0039-6028(95)00681-8

34. Martinez A., Patrykiejew A., Pizio O., Sokołowski S., J. Phys.: Condens. Matter, 2003, 15, 3107; doi $10.1088 / 0953-8984 / 15 / 19 / 312$.

35. Grabowski K., Patrykiejew A., Sokołowski S., Thin Solid Films, 1997, 304, 344; doi 10.1016/S0040-6090(97)00214-9

36. Kruk M., Patrykiejew A., Sokołowski S., Thin Solid Films, 1994, 238, 302; doi 10.1016/0040-6090(94)90071-X

37. Bucior K., Patrykiejew A., Pizio O., Sokołowski S., J. Colloid Interface Sci., 2003, 259, 209; doi 10.1016/S0021-9797(02)00203-5.

38. Martinez A., Pizio O., Sokołowski S., J. Chem. Phys., 2003, 118, 6008; doi 10.1063/1.1556850

39. Sałamacha L., Patrykiejew A., Sokołowski S., J. Phys. Chem. B, 2009, 113, 13687; doi 10.1021/jp901383v.

40. Patrykiejew A., Sokołowski S., J. Phys. Chem. B, 2010, 114, 396; doi 10.1021/jp908710e

41. Patrykiejew A., Sokołowski S., Condens. Matter Phys., 2014, 17, 43601; doi 10.5488/CMP.17.43601

42. Patrykiejew A., Rżysko W., Sokołowski S., J. Phys. Chem. C, 2012, 116, 753; doi 10.1021/jp208323b

43. Pizio O., Rżysko W., Sokołowski S., Sokołowska Z., J. Chem. Phys., 2015, 142, 164703; doi 10.1063/1.4918640

44. Suarez-Martinez I., Grobert N., Ewels C.P., Carbon, 2012, 50, 741; doi 10.1016/j.carbon.2011.11.002

45. Georgakilas V., Perman J.A., Tucek J., Zboril R., Chem. Rev., 2015, 115, 4744; doi:10.1021/cr500304f

46. Tomanek D., Guide Through the Nanocarbon Jungle, Morgan and Claypool Publishers, San Rafael, 2014.

47. Carbon Nanomaterials as Adsorbents for Environmental and Biological Applications, Carbon Nanostructures Series, Bergmann C.P., Machado F. (Eds.), Springer International Publishing, New York, 2015; doi 10.1007/978-3-319-18875-1

48. Gogotsi Y., Presser V., Carbon Nanomaterials, CRC Press, Boca Raton, 2013.

49. Yeganegi S., Gholampour F., Acta Chim. Slov., 2012, 59, 888.

50. Kowalczyk P., Chem. Phys. Phys. Chem., 2012, 14, 2784; doi $10.1039 / \mathrm{c} 2 \mathrm{cp} 23445 \mathrm{a}$ 
51. Furmaniak S., Terzyk A.P., Kowalczyk P., Kaneko K., Gauden P.A., Chem. Phys. Phys. Chem., 2013, 15, 16468; doi $10.1039 / \mathrm{c} 3 \mathrm{cp} 52342 \mathrm{j}$

52. Furmaniak S., Terzyk A.P., Gauden P.A., Kowalczyk P., Harris P.J.F., J. Phys.: Condens. Matter, 2014, 26, 485006; doi $10.1088 / 0953-8984 / 26 / 48 / 485006$

53. Kowalczyk P., Terzyk A.P., Gauden P.A., Furmaniak S., Kaneko K., Miller T.F., J. Phys. Chem. Lett., 2015, 6, 3367; doi 10.1021/acs.jpclett.5b01545

54. Tanaka H., Kanoh H., Yudasaka M., Iijima S., Kaneko K., J. Am. Chem. Soc., 2005, 127, 7511; doi 10.1021/ja0502573

55. Romo-Herrera J.M., Terrones M., Terrones H., Dag S., Meunier V., Nano Lett., 2007, 7, 570; doi 10.1021/nl0622202

56. Liu L., Nicholson D., Bhatia S.K., Chem. Eng. Sci., 2015, 121, 268; doi 10.1016/j.ces.2014.07.041

57. Terzyk A.P., Furmaniak S., Gauden P.A., Harris P.J.F., Wloch J., Kowalczyk P., J. Phys.: Condens. Matter, 2007, 19, 406208; doi 10.1088/0953-8984/19/40/406208

58. Terzyk A.P., Furmaniak S., Harris P.J.F., Gauden P.A., Wloch J., Kowalczyk P., Rychlickia G., Chem. Phys. Phys. Chem., 2007, 9, 5919; doi 10.1039/b710552e.

59. Kowalczyk P., Gauden P.A., Terzyk A.P., Furmaniak S., Harris P.J.F., J. Phys. Chem. C, 2012, 116, 13640; doi 10.1021/jp302776z

60. Furmaniak S., Koter S., Terzyk A.P., Gauden P.A., Kowalczyk P., Rychlickia G., Chem. Phys. Phys. Chem., 2015, 17, 7232; doi 10.1039/c4cp05498a

61. Palmer J.C., Moore J.D., Roussel T.J., Brennan J.K., Gubbins K.E., Chem. Phys. Phys. Chem., 2011, 13, 3985; doi $10.1039 / \mathrm{c} 0 \mathrm{cp} 02281 \mathrm{k}$

62. Furmaniak S., Kowalczyk P., Terzyk A.P., Gauden P.A., Harris P.J.F., J. Colloid Interface Sci., 2013, 397, 144; doi $10.1016 / j . j$.jcis.2013.01.044

63. Lu L., Wang S., Muller E.A., Cao W., Zhu Y., Lu X., Jackson G., Fluid Phase Equilib., 2014, 362, 227; doi 10.1016/j.fluid.2013.10.013

64. Kowalczyk P., Hołyst R., Terrones M., Terrones H., Phys. Chem. Chem. Phys., 2007, 9, 1786; doi 10.1039/b618747a

65. Mackay A.L., Nature, 1985, 314, 604; doi 10.1038/314604a0

66. Mackay A.L., Terrones H., Nature, 1991, 352, 762; doi 10.1038/352762a0

67. Lijma S., Ichihashi T., Ando Y., Nature, 1992, 356, 776; doi 10.1038/356776a0.

68. Schwartz H.A., Gesammelte Mathematische Abhandlunge, Vol. 1 and 2, Springer, Berlin, 1980.

69. Townsend S.J., Lenosky T.J., Muller D.A., Nichols C.S., Elser V., Phys. Rev. Lett., 1992, 69, 921; doi 10.1103/PhysRevLett.69.921

70. Lee H.G., Kim J., Int. J. Numer. Methods Eng., 2012, 91, 269; doi 10.1002/nme.4262.

71. Hu M., Tian F., Zhao Z., Huang Q., Xu B., Wang L.-M., Wang H.-T., Tian Y., He J., J. Phys. Chem. C, 2012, 116, 24233; doi 10.1021/jp3064323

72. Kowalczyk P., He J., Hu M., Gauden P.A., Furmaniak S., Terzyk A.P., Phys. Chem. Chem. Phys., 2013, 15, 17366; doi $10.1039 / \mathrm{c} 3 \mathrm{cp} 52708 \mathrm{e}$

73. Kowalczyk P., Parsons D., Terzyk A.P., Gauden P.A., Furmaniak S., In: Carbon Nanomaterials Sourcebook: Nanoparticles, Nanocapsules, Nanofibers, Nanoporous Structures, and Nanocomposites, Vol. 2, Sattler K.D. (Ed.), CRC Press, London, 2016, ch. 6 (in press).

74. Tylianakis E., Dimitrakakis G.K., Martin-Martinez F.J., Melchor S., Dobado J.A., Klontzas E., Froudakis G.E., Int. J. Hydrogen Energy, 2014, 39, 9825; doi 10.1016/j.ijhydene.2014.03.011

75. Wang H., Cao D., J. Phys. Chem. C, 2015, 119, 6324; doi 10.1021/jp512275p

76. Huang L., Yang X., Cao D., J. Phys. Chem. C, 2015, 119, 3260; doi 10.1021/jp5128404

77. Yang Z., Peng X., Cao D., J. Phys. Chem. C, 2013, 117, 8353; doi 10.1021/jp402488r

78. Huang L., Xiang Z., Cao D., J. Mater. Chem. A, 2013, 1, 3851; doi 10.1039/c3ta10292k

79. Huang L., Zeng X., Cao D., J. Mater. Chem. A, 2014, 2, 4899; doi 10.1039/C3TA15062C

80. Karfunkel H.R., Dressler T., J. Am. Chem. Soc., 1992, 114, 2285; doi 10.1021/ja00033a001

81. Zhao Z.S., Xu B., Wang L.M., Zhou X.F., He J.L., Liu Z.Y., Wang H.T., Tian Y.J., ACS Nano, 2011, 5, 7226; doi $10.1021 / \mathrm{nn} 202053 \mathrm{t}$

82. Ribeiro F.J., Tangney P., Louie S.G., Cohen M.L., Phys. Rev. B, 2006, 74, 172101; doi 10.1103/PhysRevB.74.172101

83. Furmaniak S., Terzyk A.P., Gauden P.A., Wloch J., Kowalczyk P., Werengowska-Ciećwierz K., Wiśniewski M., Harris P.J.F., J. Phys.: Condens. Matter, 2015, 28, 015002; doi 10.1088/0953-8984/28/1/015002

84. Nicolaï A., Monti J., Daniels C., Meunier V., J. Phys. Chem. C, 2015, 119, 2896; doi 10.1021/jp511919d

85. Werner J.G., Hoheisel T.N., Wiesner U., ACS Nano, 2014, 8, 731; doi 10.1021/nn405392t

86. Choudhury S., Agrawal M., Formanek P., Jehnichen D., Fischer D., Krause B., Albrecht V., Stamm M., Ionov L., ACS Nano, 2015, 9, 6147; doi 10.1021/acsnano.5b01406

87. Bhattacharya S., Gubbins K.E., Langmuir, 2006, 22, 7726; doi $10.1021 / 1 a 052651 \mathrm{k}$

88. Furmaniak S., Comput. Meth. Sci. Technol., 2013, 19, 47; doi 10.12921/cmst.2013.19.01.47-57 
89. Furmaniak S., Terzyk A.P., Gauden P.A., Kowalczyk P., Harris P.J.F., Koter S., J. Phys.: Condens. Matter, 2013, 25, 015004; doi 10.1088/0953-8984/25/1/015004

90. Yan Q., de Pablo J.J., J. Chem. Phys., 1999, 111, 9509; doi 10.1063/1.480282

91. Frenkel D., Smit B., Understanding Molecular Simulation, Academic Press, San Diego, 1996.

92. Setoyama N., Suzuki T., Kaneko K., Carbon, 1998, 36, 1459; doi 10.1016/S0008-6223(98)00138-9

93. Kruk M., Jaroniec M., Gadkaree K.P., Langmuir, 1999, 15, 1442; doi 10.1021/la980789f

94. Choma J., Jaroniec M., Colloids Surf. A, 2001, 189, 103; doi 10.1016/S0927-7757(01)00572-6

95. Choma J., Jaroniec M., Adsorpt. Sci. Technol., 2007, 25, 573; doi 10.1260/0263-6174.25.8.573.

96. Tylianakis E., Froudakis G.E., J. Comput. Theor. Nanosci., 2009, 6, 335; doi $10.1166 /$ jctn.2009.1040

97. Humphrey W., Dalke A., Schulten K., J. Mol. Graphics, 1996, 14, 33; doi 10.1016/0263-7855(96)00018-5

98. Kaneko K., Ishii C., Kanoh H., Hanzawa Y., Setoyama N., Suzuki T., Adv. Colloid Interface Sci., 1998, 77, 295; doi $10.1016 /$ S0001-8686(98)00050-5

\title{
Гіроїдні нанопористі вуглеці - адсорбція і особливості розділення, досліджені з використанням комп'ютерного моделювання
}

\author{
С. Фурманяк ${ }^{1}$, п.А. Гауден ${ }^{1}$, А.П. Тержик ${ }^{1}$, п. Ковальчик ${ }^{2}$ \\ ${ }^{1}$ Хімічний факультет, Дослідницька група фізикохімії вуглецевих матеріалів, \\ Університет Ніколауса Копернікуса в Торуні, Торунь, Польща \\ 2 Школа інженерії та інформаційних технологій, Університет Мердока, \\ Мердок, Західна Австралія, 6150, Австралія
}

\begin{abstract}
Адсорбція і особливості розділення у гіроїдних нанопористих вуглецях (GNC), новому класі екзотичних нановуглецевих матеріалів, вперше досліджено, використовуючи метод моделювання Монте Карло з гіперпаралельним темперуванням. Пориста структура GNC моделей оцінюється методом, запропонованим Бхатачарія і Губінсом. Всі досліджені структури є строго мікропористі. Крім того, механізми адсорбції Ar описуються на основі аналізу ізотерм адсорбції, кривих ентальпії, значень сталих Генрі, $\alpha_{\mathrm{S}}$ та кривих розподілу потенціалу адсорбції. Зроблено висновок, що при діаметрах пор близьких або менших за $0.8 \mathrm{~nm}$ домінує процес заповнення первинних мікропор. Для структур, що мають більші мікропори, спостерігається механізм заповнення первинних та вторинних мікропор. Нарешті, описано властивості розділення $\mathrm{CO}_{2} / \mathrm{CH}_{4}, \mathrm{CO}_{2} / \mathrm{N}_{2}$ i $\mathrm{CH}_{4} / \mathrm{N}_{2}$ сумішей у $\mathrm{GNC}$ і виконано порівняння з властивостями розділення моделей Віртуального Пористого Вуглецю. Гіроїдні пористі вуглеці можна розглядати як потенційні адсорбенти для розділення газових сумішей, які володіють аналогічною або навіть вищою ефективністю розділення, ніж активований вуглець з подібним діаметром пор.
\end{abstract}

Ключові слова: гіроїдні нанопористі вуглеці, адсорбція, розділення газових сумішей, моделювання Монте Карло 